\title{
Investing in Blue Natural Capital to Secure a Future for the Red Sea Ecosystems
}

\section{OPEN ACCESS}

Edited by:

David Koweek,

Ocean Visions, Inc., United States

Reviewed by:

Anna Milena Zivian

Ocean Conservancy, United States

Jean-Baptiste Jouffray,

Stockholm University, Sweden

Lida Teneva,

Independent Researcher,

Sacramento, United States

*Correspondence:

Maha J. Cziesielski

maha.cziesielski@trinomics.eu

Manuel Aranda

manuel.aranda@kaust.edu.sa

Specialty section:

This article was submitted to

Ocean Solutions,

a section of the journal

Frontiers in Marine Science

Received: 07 September 2020

Accepted: 10 December 2020

Published: 15 January 2021

Citation:

Cziesielski MJ, Duarte CM, Aalismail N, Al-Hafedh Y, Anton A,

Baalkhuyur F, Baker AC, Balke T,

Baums IB, Berumen M, Chalastani VI,

Cornwell B, Daffonchio D, Diele K

Faroog E, Gattuso J-P, He S,

Lovelock CE, Mcleod E,

Macreadie PI, Marba N, Martin C,

Muniz-Barreto M, Kadinijappali KP,

Prihartato P, Rabaoui L, Saderne V,

Schmidt-Roach S, Suggett DJ,

Sweet M, Statton J, Teicher S,

Trevathan-Tackett SM, Joydas TV,

Yahya R and Aranda M (2021)

Investing in Blue Natural Capital to Secure a Future for the Red Sea

Ecosystems.

Front. Mar. Sci. 7:603722.

doi: 10.3389/fmars.2020.603722
Maha J. Cziesielski1*, Carlos M. Duarte ${ }^{1}$, Nojood Aalismail1, Yousef Al-Hafedh², Andrea Anton', Faiyah Baalkhuyur ${ }^{1}$, Andrew C. Baker ${ }^{3}$, Thorsten Balke ${ }^{4}$, Iliana B. Baums ${ }^{5}$, Michael Berumen', Vasiliki I. Chalastani', Brendan Cornwell7, Daniele Daffonchio ${ }^{1}$, Karen Diele ${ }^{8}$, Ehtesaam Farooq ${ }^{9}$, Jean-Pierre Gattuso ${ }^{10,11,}$ Song He ${ }^{1,12}$, Catherine E. Lovelock ${ }^{13}$, Elizabeth McLeod ${ }^{14}$, Peter I. Macreadie ${ }^{15}$, Nuria Marba ${ }^{16}$, Cecilia Martin1, Marcelle Muniz-Barreto', Kirshnakumar P. Kadinijappali12, Perdana Prihartato ${ }^{17}$, Lotfi Rabaoui ${ }^{12}$, Vincent Saderne ${ }^{1}$, Sebastian Schmidt-Roach ${ }^{1}$, David J. Suggett ${ }^{18}$, Michael Sweet ${ }^{19}$, John Statton ${ }^{20}$, Sam Teicher ${ }^{21}$, Stacey M. Trevathan-Tackett ${ }^{15}$, Thadickal V. Joydas ${ }^{12}$, Razan Yahya ${ }^{1}$ and Manuel Aranda ${ }^{1 *}$

${ }^{1}$ Red Sea Research Center and Computational Bioscience Research Center, King Abdullah University of Science and Technology, Thuwal, Saudi Arabia, ${ }^{2}$ King Abdulaziz City for Science and Technology, Riyadh, Saudi Arabia, ${ }^{3}$ Department of Marine Biology and Ecology, Rosenstiel School of Marine and Atmospheric Science, University of Miami, Miami, FL, United States, ${ }^{4}$ School of Geographical and Earth Sciences, University of Glasgow, Glasgow, United Kingdom, ${ }^{5}$ Department of Biology, The Pennsylvania State University, University Park, PA, United States, ${ }^{6}$ NationalLaboratory of Harbor Works, Department of Water Resources and Environmental Engineering, School of Civil Engineering, Technical University of Athens (NTUA), Zografou, Greece, ${ }^{7}$ Hopkins Marine Station of Stanford University, Pacific Grove, CA, United States, ${ }^{8}$ School of Applied Sciences, Edinburgh Napier University, Edinburgh, United Kingdom, ${ }^{9}$ The Red Sea Development Company, Riyadh, Saudi Arabia, ${ }^{10}$ Laboratoire d'Océanographie de Villefranche, Sorbonne Université, CNRS, Villefranche-sur-Mer, France, ${ }^{11}$ Institute for Sustainable Development and International Relations, Paris, France, ${ }^{12}$ Center for Environment \& Water, Research Institute, King Fahd University of Petroleum and Minerals, Dhahran, Saudi Arabia, ${ }^{13}$ School of Biological Sciences, The University of Queensland, Brisbane, QLD, Australia, ${ }^{14}$ The Nature Conservancy, Arlington, VA, United States, ${ }^{15}$ Centre for Integrative Ecology, School of Life and Environmental Sciences, Deakin University, Burwood, VIC, Australia,

${ }^{16}$ Mediterranean Institute for Advanced Studies, Illes Baleares, Spain, ${ }^{17}$ Saudi Aramco, Dhahran, Saudi Arabia, ${ }^{18}$ Faculty of Science, Climate Change Cluster, University of Technology Sydney, Ultimo, NSW, Australia, ${ }^{19}$ Aquatic Research Facility, Environmental Sustainability Research Centre, University of Derby, Derby, United Kingdom, ${ }^{20}$ Faculty of Science, School of Biological Sciences, The University of Western Australia, Crawley, WA, Australia, ${ }^{21}$ Coral Vita, Freeport, Bahamas

For millennia, coastal and marine ecosystems have adapted and flourished in the Red Sea's unique environment. Surrounded by deserts on all sides, the Red Sea is subjected to high dust inputs and receives very little freshwater input, and so harbors a high salinity. Coral reefs, seagrass meadows, and mangroves flourish in this environment and provide socio-economic and environmental benefits to the bordering coastlines and countries. Interestingly, while coral reef ecosystems are currently experiencing rapid decline on a global scale, those in the Red Sea appear to be in relatively better shape. That said, they are certainly not immune to the stressors that cause degradation, such as increasing ocean temperature, acidification and pollution. In many regions, ecosystems are already severely deteriorating and are further threatened by increasing population pressure and large coastal development projects. Degradation of these marine habitats will lead to environmental costs, as well as significant economic losses. Therefore, it will result in a missed opportunity for the bordering countries to develop a sustainable blue economy and integrate innovative nature-based solutions. Recognizing that securing the Red Sea 
ecosystems' future must occur in synergy with continued social and economic growth, we developed an action plan for the conservation, restoration, and growth of marine environments of the Red Sea. We then investigated the level of resources for financial and economic investment that may incentivize these activities. This study presents a set of commercially viable financial investment strategies, ecological innovations, and sustainable development opportunities, which can, if implemented strategically, help ensure long-term economic benefits while promoting environmental conservation. We make a case for investing in blue natural capital and propose a strategic development model that relies on maintaining the health of natural ecosystems to safeguard the Red Sea's sustainable development.

Keywords: blue economy, Red Sea ecosystems, marine policy, sustainability, blue carbon, coral reefs, environmental policy

\section{INTRODUCTION}

The first evidence of human distribution and development along the Red Sea coastline dates back 1,25,000 years (Walter et al., 2000). Ancient local populations benefited from the marine resources provided by the Red Sea, compared to the otherwise harsh and unproductive surrounding land. It has been suggested that early utilization of the Red Sea had an important role in the dispersal of early humans out of Africa (Walter et al., 2000; Bailey, 2010) and it continues to play a vital role in supporting local communities of this region (Duarte, 2014). By providing natural resources as well as primary trade routes, the Red Sea facilitates cultural exchange and the advancement of society (Wengrow, 2010). The region has attracted the attention of explorers and been subject to substantial scientific research, with the first documented European marine biological exploration dating back to 1,761 (Hansen, 1962). The first descriptions of mangroves in western science originated from the Red Sea (Schneider, 2011), as well as the first descriptions of the major nitrogen-fixing organisms in the ocean, the cyanobacterium Trichodesmium, by Ehrenberg in 1,830 (Janson et al., 1995), as well as many Indo-Pacific scleractinian corals (Forsskål et al., 1775).

The cultural, scientific, and economic importance of the Red Sea continues today due to its unique coastal and marine environments. Latitudinal gradients in temperature, salinity, and nutrients (Raitsos et al., 2013; Chaidez et al., 2017; Duarte et al., 2018) as well as minimal freshwater inflow and high rates of evaporation, result in a wide range of habitat conditions within a relatively small geographic range (DiBattista et al., 2016). Furthermore, low precipitation and freshwater limitations have, in the past, inhibited intense development. Consequently, the region is marked by relatively low human population density and sparse distribution of economic activity (Fine et al., 2019), which has prevented the watershed from being severely altered.

Under these conditions, mangrove, seagrass, and coral reef ecosystems along the coastline of the Red Sea have provided socio-economic as well as environmental services (PES) to bordering countries (Box 1). While global climate change and anthropogenic stress have impacted the Red Sea ecosystem, its relatively undeveloped coastlines and low coastal population densities have left it less impacted compared to similar ecosystems worldwide. Long-term records indicate that Red Sea coral reefs, especially in the northern region, have experienced less severe bleaching events. Additionally, in some parts, they have shown the potential to be less sensitive to thermal anomalies than those in other regions (Osman et al., 2018). Coral reefs in the Red Sea have also exhibited the capacity for rapid recovery after bleaching events if no further stresses are imposed (Monroe et al., 2018). Additionally, while mangrove forest cover is declining globally, mangrove habitats in the Red Sea have expanded by $12 \%$ in the last 50 years (Almahasheer et al., 2016). Finally, seagrass meadows are abundant and diverse throughout the lagoons and sandy banks of the Red Sea (Qurban et al., 2019).

The relatively healthy state of some marine habitats in the Red Sea represents an abundant "blue natural capital" resource for the region. The term "blue natural capital" defines the three marine ecosystems (coral reefs, mangroves, and seagrass beds) in terms of the ecosystem services that result from their functional integrity. Hence, preserving current states and restoring natural ecosystems represents an investment in blue natural capital. This investment directly supports climate change adaptation and mitigation efforts while simultaneously creating sustainable and resilient marine ecosystems that are the foundation of a sustainable blue economic model. This model fosters development of several economic sectors that directly and indirectly benefit from marine resources, such as tourism, fishing, aquaculture, and offshore oil and gas, and less obvious benefactors, such as service providers in engineering and consulting. Additionally, when sustainable development actions are implemented in consideration of local stakeholders, communities and culture, they can have significant social benefits (Roy et al., 2018). Therefore, a sustainable "blue economy" seeks to promote economic growth and social development while ensuring the environmental sustainability of the oceans and seas (OECD, 2019). New economic development and investment opportunities under the "blue economy" aim for socio-economic growth that does not degrade the natural environment but instead depends on its continued health in order to thrive. Blue growth depends on ensuring the preservation and continued investment in blue natural capital, which, in turn, leads to continued economic growth. Thus, major development projects that are in preliminary stages around the Northern Red Sea can 


\section{BOX 1 | Marine Ecosystems of the Red Sea. \\ Coral Reefs}

Scleractinian corals are a key building block of coral reefs. By laying down calcium carbonate skeletons in nutrient-poor waters, they create habitats for other organisms and establish highly diverse and productive ecosystems over time. Furthermore, reefs dissipate wave energy, protecting the shoreline from erosion (Earp et al., 2018). Corals live in a symbiotic relationship with the unicellular algae of the family Symbiodiniaceae (LaJeunesse et al., 2018), which provide them with over 90\% of their energy demands (Davy et al., 2012), thus enabling their rapid growth. Coral reefs provide a number of ecological and economic services, including protection of shorelines, reducing coastal erosion, sustaining fisheries, and supporting tourism (see review Moberg and Folke, 1999).

Under stress, the coral-algae relationship breaks down, leading to the loss of the algae from the coral tissue and a consequent loss of color - a process known as bleaching (Cziesielski et al., 2019). Rising sea-surface temperature, ocean acidification, variation in salinity, and pollution, all of which have been linked to human-induced climate change and anthropogenic activities, are increasingly threatening corals globally, including corals in the Red Sea (Hughes et al., 2018). Consequently, the rate and intensity of coral bleaching events (Hughes et al., 2018), outbreaks of disease (Mohamed and Sweet, 2019), as well as other forms of coral reef degradation (Knowlton et al., 1990; McCook et al., 2001), have continued to increase at alarming rates around the globe.

Coral reefs span the entire coastline of the Red Sea and are known for their high productivity, biodiversity, and endemism (Berumen et al., 2013). Due to the gradient of environmental conditions across the Red Sea, coral reefs exist in a range of habitats that have resulted in heterogenetic patterns of bleaching and stress exposure. The northern Red Sea coral reefs, particularly in the Gulf of Aqaba, have demonstrated significant thermal tolerance and bleaching resilience (Kleinhaus et al., 2020). Meanwhile, more severe bleaching events have been recorded in the central and southern Red Sea (Osman et al., 2018). Most recently, the 2015/2016 El Niño event broadly affected reefs in the southern Red Sea, causing high mortality (Monroe et al., 2018; Voolstra and Berumen, 2019) and an estimated decline in coral cover of about 45\% (Anton et al., 2020b). The full extent of thermal stress on corals and bleaching events has been suggested to remain vastly underassessed in the Red Sea (Genevier et al., 2019).

\section{Mangroves}

Mangrove trees have adapted to live in (sub-) tropical saline intertidal zones. They are a nursery for many commercially-important shellfish and fish species that migrate to coral reefs and the open ocean once they have reached maturity (Dorenbosch et al., 2006; Mumby et al., 2007). An array of goods can be harvested from mangroves, including fisheries resources, timber, and firewood (Spalding et al., 2010; Ward et al., 2016). Mangrove vegetation also provides ecosystem services, such as sediment trapping and erosion protection, flood protection, and nutrient cycling (Duarte et al., 2013; Saderne et al., 2018). Additionally, mangrove forests are capable of trapping and sequestering pollutants, such as heavy metals, hydrocarbons, and plastic particles, from the water column (Ashok et al., 2019; Martin et al., 2019, 2020; Rabaoui et al., 2020). Mangroves' capacity to improve water quality is particularly beneficial for aquaculture practices. Studies have shown that mangroves can act as natural filtration systems, capable of reducing inorganic nitrogen and phosphate while increasing oxygen levels and thereby increasing the resilience of aquaculture farms to disease outbreaks (Peng et al., 2009; Ahmed and Glaser, 2016; Ahmed and Thompson, 2019). Moreover, mangrove ecosystems are noted for their large carbon stores per area, known as "blue carbon" (see section Financial investment strategies and Blue Carbon). In the Red Sea, mangroves form mainly short monospecific stands of Avicennia marina, with few occurrences of Rhizophora mucronata (Almahasheer et al., 2016).

\section{Seagrass}

Seagrass meadows are another major vegetative coastal habitat and are closely associated with other ecosystems, including mangroves and coral reefs. There is strong evidence that healthy seagrass beds enhance the productivity of these other systems. Seagrass meadows provide shelter and food for many marine organisms and serve as nurseries for commercially-important fish and shellfish species (Jackson et al., 2015; Nordlund et al., 2018; Unsworth et al., 2019). Their high rates of primary production oxygenate and remove nutrients from the water column. Their roots trap sediment, maintaining water clarity and quality, contributing to stabilization and protection of the coast from erosion (Potouroglou et al., 2017). Through photosynthesis, seagrass can also sequester $\mathrm{CO}_{2}$ from the atmosphere, which can then be transported through their roots and trapped in the sediment (Howard et al., 2017). Thus, along with mangroves, seagrass meadows are important contributors to carbon sequestration and storage (Garcias-Bonet et al., 2019; Shaltout et al., 2020). Specifically, in the Red Sea, two species of seagrasses, Halophila stipulacea, and Thalassia hempricii, appeared as the most vulnerable to warming and will likely be affected by future thermal stress in the southern region (Anton et al., 2020a).

\section{Connected impacts on marine ecosystems}

Mangrove, seagrass, and coral reef ecosystems are all interconnected, depending on and facilitating one another's healthy existence (see review Earp et al., 2018). Most recently, these marine ecosystems of the Red Sea have been shown to also provide thermal refugia for coastal ectotherm animals, whereby the photosynthetic activity, enhanced by increased temperatures, favors seawater oxygen supersaturation that fuels the peak oxygen demand of animals, thus protecting the fauna during the summer thermal stress (Giomi et al., 2019).

Development, aquaculture, and associated increasing pollution across the coast pose immediate threats to these ecosystems' health, not only through land use and destruction but also through changes in the topography of the coast (PERSGA, 2004). In addition, consequences of climate change (such as sea-level rise, temperature increase, higher frequency of storms, and changes in ocean currents) present equal if not greater threats to these vegetated marine habitats (Ellison, 2015). Seagrass distribution and survival are controlled by air and sea temperatures, as well as light availability (Short et al., 2007; Ward et al., 2016; Earp et al., 2018). Loss of mangroves and seagrasses leads to the subsequent loss of ecosystem services, including current and future carbon and pollutant sequestration capacity, as well as the release of previously sequestered carbon and pollutants through oxygenation and remobilization of sediments (Donato et al., 2011; Mcleod et al., 2011; Lovelock et al., 2017; Ashok et al., 2019).

ensure significant long-term benefits, across a broad range of stakeholders, by incorporating investments into increasing blue natural capital into their designs. Hence, the Red Sea represents an opportunity for the region to establish a new vision and become a global leader in designing a sustainable socio-economic growth model that is linked to the building and conservation of "blue natural capital."

Here, we investigate opportunities that will enable the region's continued economic growth while ensuring longterm sustainable development. Our aim is not to revise the trajectory of Red Sea ecosystems under a business-as-usual scenario. Instead, we aim to formulate a new vision that places the marine environment at the center while still enabling sustainable economic development that benefits community and nature (Figure 1). In a similar fashion to the "one health" directive (Destoumieux-Garzón et al., 2018), initially proposed ten years ago, the proposed model re-evaluates economic growth and development incentivizing the commercial viability of environmental protection and conservation through investment opportunities. We advocate "blue natural capital" investment opportunities and present sustainable development approaches that, if executed appropriately, will encourage growth and 

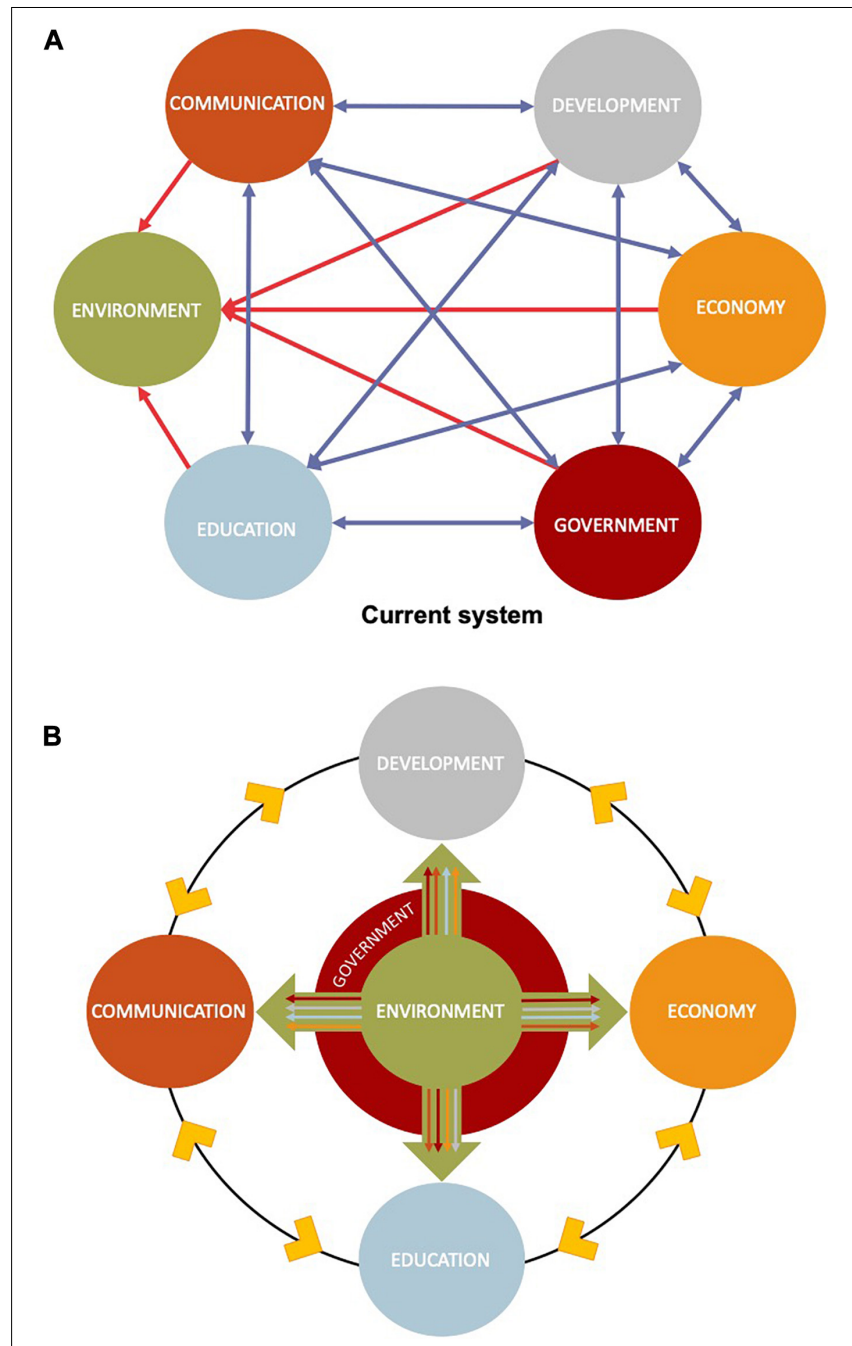

Sustainable Development

FIGURE 1 | Strategic development models have relied on the expolitation of the environment. Investing in blue natural capital and a sustainable future requires an evolution of the current development model (Figure 1A). A revised model needs to center the environment, valuving creation over destruction and regulating management through well-planned and executed governmental pollicies (Figure 1B). (A) In the current system, all sectors are interconnected but primairly linked to the environment through exploitation (red arrows). In this model there is a lack of acknowledgment of the impact of the environment on the success on the prosperity of any developmental project. Economic opportunities are therefore often missed, and the importance of the environment is undervalued. Thus the incentive towards protecting, preserving, and rebuilding the health of natural ecosystem is reduced. Consequently, finacial benefits and long-term growth are reduced and threatened. (B) The newly proposed environment centered (Sustainable) development model (presented here) aims to recognize the socio-economic importances of the environmental's health on strategic development, by placing it at the center. The success and failure of each sector directly impacts the environment as well as indirectly itself and all others. When the environment is placed at the core of the system, the inter-connectivity of the sectors is clearly linked through the sustained health of eco-system - the environmental is effectively the heart of social and economic wealth. In this model governance is not a sector like any other; governments are fact of the key custodains of the natural environments. Government collaborations

(Continued)
FIGURE 1 | Continued

proactive pollices, and enforcement are required and essential to ensure net-positive outcomes of the environment as a whole and thus, the validity of all other sector. Hence governments have the responsibility to implement govermance arrangements that act as a shield, preventing unsustainable use and negative interactions of the other sectors with the natural environment.

expansion of blue natural capital and provide both economic and environmental benefits for the foreseeable future.

\section{THE CASE FOR INVESTING IN BLUE NATURAL CAPITAL}

The Organization of Economic Co-operation and Development reported that blue economy industries contributed $\$ 1.5$ trillion to the global market in 2016, or approximately $2.5 \%$ of the world's gross added value (OECD, 2016). Blue economic activities and investments have been steadily rising (European Comission, 2018; Wenhai et al., 2019; Jouffray et al., 2020) and, importantly, are predicted to increase their economic value by 2,030 (OECD, 2016). Underpinning the blue economy's success is the continued health of ecosystems and their services. Sustainable development approaches are predicted to increase the blue economy's value by USD $\$ 500$ billion more than in a businessas-usual scenario by 2,030 - which will continue to increase in the future (OECD, 2016). A sustainable blue economy could generate 43 million jobs by 2,030, 7 million more than under an unsustainable scenario (OECD, 2016). Development of the fishery and tourism sectors will contribute to higher employment rates, which coincidently depend on healthy coastal and marine environments to do so.

Considering that tourism and fisheries, with artisanal fisheries accounting for $49 \%$ of the catch (Tesfamichael, 2016; Fine et al., 2019), are among the most important economic activities of the Red Sea, investing in blue natural capital can deliver significant and measurable long-term benefits to local communities and governments alike. First, signs of anthropogenic impacts on the loss of natural marine habitats that support both of these economies are already evident along the coast (Box 1). Increasing environmental pressure, through unprecedented development and investment in infrastructure along the coast of the Red Sea (Kleinhaus et al., 2020), requires direct investment into ensuring the best possible outcome for blue natural capital to allow stakeholders to enjoy the benefits of a blue economy. Next, the predicted population growth in the region (Fine et al., 2019) will also increase pressure on marine ecosystems and services, through direct effects on their health, as well as increased dependence on natural resources. Further, other anthropogenic impacts (in addition to uncontrolled urbanization and coastal development), such as those posed by marine resource exploitation (e.g., oil and natural gas extraction or deep-sea mining) might cause as of yet unknown impacts to a part of the Red Sea ecosystem that is least well understood (Halfar and Fujita, 2002). Thus, unsustainable blue natural capital management would likely have severe economic and social 
consequences, through reduced livelihood and food security across Red Sea nations (Visbeck et al., 2014; Hamza et al., 2017).

Conserving the Red Sea's valuable habitats offers windows of opportunities to position the region as a global investment hub and a potential leader of sustainable development. We acknowledge that there is an ongoing debate regarding the success of conservation in light of development (Miller et al., 2011; Caro et al., 2012; Kareiva and Marvier, 2012; Soulé, 2013). However, we advocate for a vision that entails not only conserving but also growing blue natural capital to enhance natural resources, which will benefit local communities and society as a whole (Figure 1). We've formulated an action plan (Table 1), that outlines suggested key steps to be taken by nations of the region, in terms of political international collaboration and economic investments in communities, education, nature and research. We elaborate on the steps of our action plan and related investment opportunities below, focusing on those strategies that promote health and prosperity for both environment and economy. An important factor among all our action steps is that the development and allocation of marine and coastal spaces and resources should not lead to erosion of opportunities and rights of communities - a phenomenon that's been termed as “ocean grabbing." Bennett et al. (2015) defined ocean grabbing as "dispossession or appropriation of marine resources or spaces, robbing communities of use, control or access to resources on land or sea." Although our model for sustainable development places environment at the center, we urge for equity and benefit sharing across all our proposed actions. The discussed investment opportunities below, focus on those strategies that promote health and prosperity for both environment and economy. We've categorized our action steps for blue natural capital investment opportunities tailored to the Red Sea into three categories: financial strategies, ecological innovations, and sustainable coastal development.

The outlined steps are ranked by their urgency, followed by the estimated costs to highlight that the most urgent actions are not necessarily the most economically challenging ones. Rather, the steps of highest priorities require the collaboration and communication between a number of actors, which may pose a challenge in itself. The action plan steps were identified during a research workshop (held at King Abdullah University of Science and Technology, Saudi Arabia, March 11-14th, 2019) which brought together national and international experts from academia, industry, and government to discuss the current state of the Red Sea blue economy and to develop feasible strategies to insure a sustainable future. An initial SWOT analysis, followed by an analysis of internal and external opportunities across sectors, led to the below action plan that was approved by representatives of various backgrounds.

\section{FINANCIAL INVESTMENT STRATEGIES FOR THE BLUE ECONOMY}

Financial strategies and instruments to conserve and rebuild blue natural capital already exist. These include biodiversity offset and credits (Curran et al., 2014), banking credits (Fujita et al., 2013), restoration of natural capital credits (Blignaut et al., 2014), environmental (green/blue) bonds (Shishlov and Morel, 2016), portfolios of ecosystem services (Fujita et al., 2013), taxes, subsidies, charges, and fines, for example (Stavins, 2001; Bailey, 2002). The green economy (which has to date primarily focused on sustainable development without degrading terrestrial systems) has been modeling how such market-based incentives, which apply monetary values to products and activities/services of the environment, can support environmental management in the blue economy.

The term Blue Carbon refers to organic carbon captured and stored by vegetative coastal habitats, such as seagrass meadows and mangrove forests. These ecosystems can lock carbon in underlying sediments, into living biomass above and below ground, and within non-living biomass for millennia (Duarte et al., 2004; Nellemann et al., 2009; Mcleod et al., 2011). Although these ecosystems cover an area of less than $0.02 \%$ of the seafloor, they account for $50 \%$ of the carbon buried into oceanic sediments (Duarte et al., 2013; Box 1). Loss of these ecosystems has been of significant concern due to the potential implications of extensive conversion of standing carbon pools below ground into the atmosphere as greenhouse gas (Duarte et al., 2010; Hejnowicz et al., 2015; Lovelock et al., 2017).

Blue Carbon ecosystems can be integrated into financial incentive strategies, as blue carbon credits could be used to offset carbon emissions and be traded in the carbon markets (He, 2016). Since the sequestration of carbon in these habitats is highly efficient (Sanderman et al., 2018), conserving, restoring, and expanding the blue carbon ecosystems of the Red Sea could also attract lucrative international investments by providing a framework for businesses to become carbon neutral. To incentivize local investment into the protection and conservation of blue carbon habitats, payment for PES schemes can be implemented. PES allows for providers of PES (i.e., local communities) to receive income or funds from buyers interested in using the perceived benefits that these habitat offers (i.e., private organizations and service sectors) (Lin and Nakamura, 2012; Hejnowicz et al., 2015). When incorporated into the aquaculture industry, such financial strategies, along with education, could lead to the development of sustainable integrated aquaculture-mangrove systems (Ahmed and Glaser, 2016). In this case, catastrophic losses of mangrove ecosystems (which have occurred in many other world regions and are causally linked to coastal aquaculture practices) could be avoided (Box 1). Implementing these financial strategies (amongst others) not only diversifies the economy but also promotes communities to feel a sense of responsibility and take management actions, while enhancing and ensuring the long-term maintenance of their livelihoods. This concept of communities taking responsibility for their local environment and resources is often referred to as stewardship and can be another pathway to ensuring equal distribution of benefits among communities.

The success of blue carbon, or any environmental finance scheme for that matter, is tightly linked to policy and governance mechanisms being established that encourage implementation and enforce accountability (Macreadie et al., 2019; Figure 1, 
TABLE 1 | A suggested action plan on how to ensure the sustainable development and preservation of blue natural capital in the Red Sea region

\begin{tabular}{|c|c|c|c|}
\hline $\begin{array}{l}\text { Urgency } \\
(0=\text { Low, } \\
1=\text { Medium, } \\
2=\text { High, } \\
3=\text { Critical })\end{array}$ & $\begin{array}{l}\text { Estimated } \\
\text { cost }\end{array}$ & Action & Actors \\
\hline 3 & Low & $\begin{array}{l}\text { Identify and formulate a collective vision for the Red Sea } \\
\text { with trans-national partners. }\end{array}$ & National Authorities, Red Sea Authority, PERSGA. \\
\hline & Medium & Assessing the Blue Natural Capital of the Red Sea & Red Sea Authority, PERSGA, National Authorities, \\
\hline
\end{tabular}

Assessing the Blue Natural Capital of the Red Sea

evaluating ecosystem status, health, and biodiversity

followed by monitoring of changes.

Low

Conduct risk assessments of Blue Natural Capital of the

Red Sea (vulnerability to climate change).

Raise large development projects in the Red Sea (NEOM,

Amaala, and The Red Sea Project) to exemplars of

economically sound models of development in the $21 \mathrm{st}$

century.

$3 \quad$ Low/

Overcome Red Sea environmental data deficiency by encouraging data sharing and creating a single porta (infrastructure) for curating and collecting Red Sea environmental data.

Strengthen current institutions and creating necessary ones, which are empowered to enforce legislation and achieve determined outcomes (i.e., The Red Sea Authority).

Establish a rapid response mechanism to environmental crises (e.g., coral bleaching, industrial accidents etc.

including detection mechanisms (e.g., involving local

community, and environmental police) and the deployment

of restoration and mitigation measures.

Develop restoration measures to recover the impacted coral reefs in the Red Sea and globally. retaining local traditions and use them to maintain local ecosystems, revamp national curricula to include values and risks of local ecosystems.

Red Sea Authority, PERSGA, National Authorities, and Scientific Community to inform design.

Scientific community.

PIF, Private Sector.

Scientific Community, National Authorities, Red Sea Authority, PERSGA, Industry (Oil and Gas,

Ecotourism etc.), and Citizen Science.

National Authorities, Regional Leaders.

Red Sea Authority, PERSGA, Scientific Community and Local Community Stakeholders.

Red Sea Authority, PERSGA, and MEWA

Scientific Community, Ministry of Education Ministry of Environment, Red Sea Authority,

PERSGA, Industry, and Local Commun

Stakeholders.

National Authorities, Red Sea Authorities, PERSGA, Scientific Community, Industry, and Loca

Community Stakeholders.
International partnerships; developmental and economic innovation, cooperative environment.

Unlock full economic potential of region, create global leadership opportunities, and promote research and critical environmental protection.

Inform conservation and research strategies.

Competitive leadership and innovation in coastal development, development of intellectual property, and spin-offs around new technologies for sustainable development.

International collaborations; Red Sea as a unique environment, establishing natural resource and their sustainable utilization. Increase in social awareness and ocean literacy.

Ensure the long-term sustainability of the blue natural capital supporting a sustainable Red Sea economy.

\section{Mitigate social and economic impacts}

Restoration technology to deploy globally, generating economic opportunities, raise awareness in the public, and develop a skilled labor force and industry around coral reef restoration.

Preserve and value local traditions, adapt and evolve national curricula to further enhance the capacity and competitiveness of the workforce.

Development of economy, employments, tourism, development of new technologies, while reducing conflicts, and economical risks. 
Table 1). However, it has been recognizably difficult to incorporate certain schemes into markets due to inadequacies in assessing the value of PES. Indeed, price tags on PES have been heavily criticized for being somewhat oversimplified, i.e., not considering the costs and benefits of biodiversity, as well as the additional cost of rehabilitating destroyed ecosystems (Wright et al., 2006; Rinkevich, 2015). Many questions regarding ecosystem services' actual values are still unanswered and require evaluation (Himes-Cornell et al., 2018). For the Red Sea, unanswered questions include: what are ecosystem services like nutrient cycling, coastal protection, biodiversity, and $\mathrm{CO}_{2}$ sequestration actually worth?

Although progress has been made in how to improve financial strategies for the blue economy, there is still room for improvement (i.e., funding opportunities to overcome funding gaps and incentivizing sustainable blue investments to mature the market) (van Aalst et al., 2018). Importantly, they should not be viewed in isolation from or as an alternative to direct investment into conservation and restoration of marine ecosystems. Instead, economic decision-makers should consider conservation and restoration at every step to enhance sustainable growth both in current and future development strategies. Ultimately, however, whichever financial strategy is being implemented, it is essential that they provide long-term financial benefits to local communities. Securing community engagement and ensuring that the projects will not have unexpected consequences, such as creating inequities within communities (Vierros, 2013) or allowing the exploitation by private sector or other partners (Bennett et al., 2015), is essential for success.

\section{DEVELOPING ECOLOGICAL INNOVATIONS ALONG THE RED SEA}

The development of new methods and technology for rebuilding and conserving marine habitats and, therefore, protection of blue natural capital can create important sought-after blue technology, marine bio-products, and associated intellectual property. These new discoveries could lead to new business models, attract investment funds, and create new marine industries.

For example, the Red Sea coral reefs are considered to be among the least vulnerable to climate change impacts, with lethal thermal limits of around $36^{\circ} \mathrm{C}$ (Anton et al., 2020b), placing them in a globally important position to potentially facilitate the regeneration of other coral reefs in the future (Hoegh-Guldberg et al., 2018). In a Global Coral Reef Conservation Portfolio study, coral reefs of the Red Sea were assessed to provide a good return on investment with low risk of loss (Hoegh-Guldberg et al., 2018). Compared to the southern Red Sea, northern parts are characterized by cooler sea surface temperatures and lower temperature maxima (Chaidez et al., 2017; Box 1). In the Gulf of Aqaba, coral reefs have withstood significant warming events without severe mass-bleaching, successfully sustaining a healthier state (Osman et al., 2018). Indeed, northern Red Sea corals have higher thermal resilience than elsewhere, and hence, the northern region has been deemed a potential coral refuge to increasing ocean temperatures (Fine et al., 2013; Krueger et al., 
2017; Osman et al., 2018). In the Central Red Sea, two coral species (Pocillopora verrucosa and Stylophora pistillata) have been described to have high lethal thermal limits of around $36^{\circ} \mathrm{C}$ (Anton et al., 2020b). Therefore, coral species inhabiting this region are suitable candidates for restoring and protecting coral reef health worldwide (Kleinhaus et al., 2020). Harnessing the natural resilience of Red Sea corals could allow the re-seeding of reefs globally that have been severely degraded by temperatureinduced bleaching events. However, significant research is required to ensure success. Fundamentally, characterizing the traits that make certain coral species more resilient than others is required and is currently being investigated (Dixon et al., 2015; Howells et al., 2016; Kirk et al., 2018; Manzello et al., 2018). Understanding genetic traits and conditions responsible for higher thermal resilience in corals can enable effective breeding of offspring with desired traits. Research into coral genetics and development of optimized methods for upscaling the spawning and rearing of corals ex situ (Craggs et al., 2017) could assist global efforts in accelerating the rate of naturally occurring evolutionary processes, known as assisted evolution or assisted gene flow (van Oppen et al., 2015, 2017). The genetic resources obtained would also significantly contribute to establishing a coral gene bank for future coral restoration (Hagedorn et al., 2019). Important here is that the development and distribution of genetic resources is equitably applied across key actors (see Table 1). However, some have suggested we move with extreme caution when implementing such practices linked with upscaling reef restoration, including but not limited to aspects in and around assisted evolution or assisted gene flow (i.e., the use of probiotics to increase thermotolerance and/or disease resistance; (Sweet et al., 2017), since any kind of human intervention might come with unforeseeable risks for the local flora and fauna. While some of these risks could be mitigated using highly controlled environments and constant monitoring, it is nigh impossible to contain marine organisms in an open environmental setting like a natural coral reef. Regardless, the Red Sea holds the potential for exploration of much unexplored marine genetics and presents itself as an invaluable investment opportunity into genetic resources (Fine et al., 2019).

In contrast to the north, the central and southern Red Sea coral reefs have experienced severe thermal bleaching events (Monroe et al., 2018; Osman et al., 2018; Box 1). The loss of reef habitat provides an opportunity for another significant category of investment: rebuilding and restoring coral reefs. While the northern Red Sea provides valuable opportunities for genetic research in coral reefs, the southern Red Sea offers a testbed for novel reef restoration methods. Economic assessments have shown that although coral reefs have the highest value with respect to natural capital, they have the lowest benefit-cost ratio due to relatively high restoration costs (de Groot et al., 2012). Additionally, restoration of coral reefs is complex and has so far been difficult to achieve on a large scale (Blignaut et al., 2014). Thus, there is a market interest in developing new technology and methods of scaling coral reef restoration (Baums et al., 2019; Schmidt-Roach et al., 2020). The degraded reefs of the southern Red Sea allow for the testing and optimizing of restoration tools such as in situ coral propagation (Schopmeyer et al., 2017), larval re-seeding (Chamberland et al., 2017), and recruitment (Liversage and Chapman, 2018) and coral transplantation (Horoszowski-Fridman and Rinkevich, 2016). Selecting new restoration sites for long-term success will require significant research and environmental monitoring to ensure the highest chance of success (Bayraktarov et al., 2016; Suggett et al., 2019). Furthermore, the intellectual capital of research institutes across the region can foster the development of innovative technology and locally tailored approaches associated with reef restoration. Topics could include, amongst others, testing new larval seeding and recruitment protocols, creating nurseries and trialing new designs, establishing labbased coral spawning that allows for year-round sexual reproduction, and developing cryo-preservation methods for future interventions. For these to be successful, scientific and local communities will have to be incentivized to collaborate (see Table 1).

Finally, identifying and understanding the role of bacterial communities in the Red Sea has been of increasing interest for innovative restoration and protection of reefs and coastal habitats. The bacterial communities associated with animals, plants, seawater, and sediments are emerging as important components of ecosystem diversity (Cuellar-Gempeler and Leibold, 2018), regulating plant and animal stress resilience and habitat functioning (Trevathan-Tackett et al., 2019). Recent studies have indicated that bacterial communities may support coral resistance to bleaching (Rosado et al., 2019) or may elicit root growth for an earlier establishment of mangrove propagules (Soldan et al., 2019). Therefore, research into the bacterial communities of the Red Sea and associated provide another major avenue of "blue gold," i.e., potential bioproducts beneficial to the organisms in question but also to humans in the form of novel drug discovery (Blockley et al., 2017).

These active forms of protection and restoration of coral reefs are linked to one another; research in the northern Red Sea has a high potential to result in new selective breeding and seeding programs that can then be tested and implemented in the more damaged and degraded southern ecosystems. Since these strategies are at an early stage, ecological innovation investments presented here focus on advancing technology as well as increasing research funding, generating knowledge, and fostering transnational collaboration.

\section{INTEGRATING MARINE HABITATS IN COASTAL INFRASTRUCTURE DEVELOPMENT}

When developing strategies for the future of blue natural capital in a socio-economic context, a third avenue, besides conservation and restoration, must be considered for the investment to be profitable in the long term. Population growth and planned largescale coastal developments could be seen as a significant risk to the future of the Red Sea ecosystems, as seen in the impacts of 
other regions, such as the Arabian Gulf (Burt and Bartholomew, 2019). However, if carefully planned, managed, and executed, they could become an internationally significant investment and development prospects that are made more valuable by the blue capital that they conserve and grow. Future coastal development projects demand a commitment to sustainability with a focus on balancing ecosystem, social, and economic benefits. Important here, as with other action steps, is that the development and allocation of marine, and coastal, resources do not lead to ocean grabbing and the consequent erosion of opportunities and rights for local communities. Integrating the marine environment and blue natural capital into community conscious coastal development allows Red Sea projects to lead the way and take advantage of innovative technology and investment strategies while securing the region's desired blue natural capital.

To date, coastal infrastructure has been designed with limited consideration of marine habitats, consequently debilitating surrounding ecosystem services. Sustainable coastal development technology and nature-based solutions are continuously expanding and include not only the creation of artificial habitats (Feary et al., 2011; Dafforn et al., 2015) but also new approaches in constructing coastal infrastructure supporting the establishment of marine ecosystems (Ido and Shimrit, 2015). Incorporating marine habitats into development projects enables blue natural capital and socio-economic investments to grow together. Large development projects, such as those related to Saudi Arabia's Vision 2,030 (i.e., NEOM, The Red Sea Project, and Amaala), could be exemplary economically sound models that achieve net-positive conservation impact and social equitability. Besides including current methods of ecosystem engineering, such as using eco-friendly concrete and other methods of ecological enhancement of marine infrastructure (Ido and Shimrit, 2015; Hall et al., 2018; MayerPinto et al., 2019), cities of the future can invest in new technology and development strategies. Examples include (but are not limited to) the incorporation of coral nurseries and coral farms into ecological esthetics of coastal cities, coastal mangrove forest boardwalks and piers that serve as natural attractions as well as coastal protection (Satyanarayana et al., 2012), and building threat mitigation into development plans to protect coastal marine ecosystems. Obviously, these initiatives should also target the use of renewable energy and zero-emission technologies. It is worth mentioning that the implementation of coastal ecological engineering and nature-based solutions can also balance carbon emissions and removal, thus facilitating the establishment of a circular carbon economy in the region (Langergraber et al., 2020). However, the implementation of these strategies may not be feasible for all nations, depending on their economic and financial resources. These imbalances must be considered when proposing a proactive and coordinated approach (see Table 1, and section "Collaborative Governance for Red Sea ecosystems). Nonetheless, the Red Sea region could lead innovative development strategies of the 21 st century by incorporating current ecological engineering tools and investing in the advancement of new technology where possible.
Needless to say, investing in the incorporation of marine habitats into coastal development would allow the expansion of the ecotourism sector and bring the Red Sea to a global audience. Marine tourism, specifically reef tourism, is already one of the major economic activities of many Red Sea bordering countries (Fine et al., 2019). With many new Red Sea tourism projects in development, marine tourism's interest is expected to increase steadily. Importantly, growth of the tourism sector into a major economic player can lead to new management programs built around stewardship as well as new research partnerships ${ }^{1,2}$. Therefore, economic and environmental instruments associated with novel ecotourism concepts are an important and profitable investment opportunity that can diversify the local economies (Schmidt-Roach et al., 2020). Furthermore, ecotourism concepts can be directly linked to environmental education enhancement as these attractions allow the general public to experience, appreciate, and value natural marine habitats. Particularly, vegetated ecosystems are easily made accessible to the public through piers or park structures if appropriate infrastructure and management are applied. Environmental education investments can act as platforms for the conservation of local culture and capacity development, ultimately leading to new service opportunities in other economic sectors (Blignaut et al., 2014; Fine et al., 2019).

It is important that nations and developers strive to give equal priority to the quality and quantity of tourism. The future of sustainable ecotourism depends on increasing the scale of tourism, resulting in environmental stewardship, incentivizing best practice methods, and reducing environmental impacts (Fujita et al., 2013).

\section{COLLABORATIVE GOVERNANCE FOR THE RED SEA ECOSYSTEMS}

Failing to invest in adaptive management strategies, those aimed at protecting and maintaining blue natural capital, will inevitably catalyze environmental degradation and a significant lost opportunity to harness natural resources that would benefit marine habitats and the regional economy. Investing in conservation and building the Red Sea's blue natural capital offers avenues to diversify the regional economy with globally relevant assets and lead international efforts in sustainable development efforts. However, sustainable governance, particularly across borders, is necessary in order for these opportunities to exist and for blue natural capital to grow (see Table 1).

Marine protected areas (MPA) and marine spatial planning (MSP) are fundamental tools utilized by governments (globally) to assist in the management and protection of coastal and marine ecosystems (i.e., to conserve blue capital). MSP constitutes

\footnotetext{
${ }^{1}$ https://www.theredsea.sa/newsroom/the-red-sea-development-company-andkaust- unveil-groundbreaking-approach-to-conservation-and-developmentplanning

${ }^{2}$ https://www.businesswire.com/news/home/20191003005791/en/AMAALAPartners-With-the-Prince-Albert-II- of-Monaco-Foundation-the-CentreScientifique-de-Monaco-and-Oceanographic-Institute-to-Protect-andPreserve-Marine-Environment
} 
a public process of analyzing and allocating the spatial and temporal distribution of human activities in marine areas to achieve a balance in ecological, economic, and social objectives (Ehler and Douvere, 2009). The principles of MSP are often used to design MPAs worldwide, as MSP can help ensure compensation and replacement for interference in the natural environment (Schachtner, 2017). MPAs are defined regions that manage specific conservation objectives, and some can be notake zones to protect local fish stocks or define areas banning mangrove wood harvesting. MPAs are fundamental for the MSP process. They ensure the sustainable use of natural resources while supporting the blue economy concept and providing investment opportunities in the marine sector (Kelly et al., 2014).

A number of MPAs have been declared in Red Sea waters, with many more under review (Marine Conservation Institute, 2019). Egypt has led by example through the implementation of MPA's back in 1,986. However, Egypt struggled to implement and properly enforce MPA's due to a series of socio-economic factors such a shortage of alternative resource dependencies (e.g., alternative income for fishermen who've lost access to fishing grounds), raising awareness and compliance mechanisms (Marshall et al., 2010; Samy et al., 2011). Lessons learned in developing successful MPA's in Egypt can be used to inform strategic management and implementation throughout the rest of the region. These include primarily the insight that the reduction of fishing and other anthropogenic pressures cannot be achieved through regulations alone but that they depend on the voluntary compliance of the local communities in order to be successful in the long-term. This, however, requires the development and implementation of educational programs aimed at increasing the awareness of local stakeholders as well as clear resource management plans, enforcement of regulations and alternative sources of income where necessary (Mabrouk, 2015).

The Regional Organization for the Conservation of the environment of the Red Sea and Gulf of Aden (PERSGA), an intergovernmental body dedicated to the conservation of coastal and marine environments of the region, and similar organizations will play an important part in facilitating the exchange of information and ensuring the success across borders. However, so far, relevant policy frameworks promoting MSP have not yet been established in any of the areas considered by PERSGA.

The first step for an MSP application in the Red Sea has recently been made through the Red Sea Project, a core component of Vision 2,030, which aims to develop the tourism sector of the Kingdom of Saudi Arabia (The Red Sea Development Company, 2020). Unfortunately, the absence of formal MPA, MSP, and general fisheries management arrangements in the broad area, results in habitat destruction and conflicts between industry and artisanal fisheries (Hariri et al., 2002). Fishing communities in the region have had traditional governance mechanisms, which have been overwhelmed by large scale acceleration of industrial fishery sector (Feidi, 2009). Saudi Arabia presents a unique case in that the citizens own the traditional fishing fleets, but the sector is heavily dependent on immigrant workers (Feidi, 2009). In addition, marine ecosystems are interconnected and transnational by their very nature, i.e., they do not restrict themselves to country borders. Hence, collaborative efforts to manage threats occurring beyond national boundaries and accounting for connectivity between ecosystems are essential to manage and sustainably develop marine resources to their maximum potential (Roberts, 1997). This is particularly important when discussing fisheries management and stock quotas. The region offers many opportunities for multi-lateral development that ensure traditional communities knowledge and resources are incorporated into modern governance institutions, through focused capacity building (Feidi, 2009). Establishing transnational collaborations incentivizes shared stewardship practices and fosters a culture of peace and unified prosperity to the coastal nations sharing interdependent marine resources (Table $\mathbf{1}$ ).

For policy frameworks to be successfully implemented, managed, and maintained, conflict resolution mechanisms and incentives for coordination and cooperation must be in place. This also requires adequate assessment and monitoring strategies of marine ecosystems, with a motivation to share data. Additionally, procedures must be developed to conduct common environmental impact assessments (EIA) focusing on biodiversity risks of new infrastructure investments. This will require transparency, baseline data collection, identification of costs and benefits, and implementing mitigation measures (see "Actions" as well as "Actors" in Table 1). Without such mechanisms and robust data, effective management and planning cannot occur. This would result in a lack of accountability that could risk unsustainable and likely destructive uses of blue natural capital. Successful Red Sea management requires sound scientific knowledge describing its local and regional status. Nations will have to develop and communicate effective datacollection frameworks that can be used for evaluation and longterm monitoring. Initiating baseline datasets is paramount to overcome the current data deficiency in the Red Sea and to accurately inform policy actions. Continued monitoring and assessment are necessary to ensure that implemented policies are effective and have a measurable performance indicator against established goals (Day, 2008). Citizen-science programs and engagement of local communities can be a valuable asset, as well as directly contributing to local education and awareness programs (Marshall et al., 2012; Branchini et al., 2015). Additionally, stakeholder nations must invest in conducting risk assessments of blue natural capital in the Red Sea to understand vulnerabilities (i.e., pollution, climate change) and to protect and ensure growth, rather than loss, of assets and investment (Table 1). Finally, in order to facilitate collaboration across borders, joint targets and objectives must be set, outlining roles and responsibilities that are clearly aligned with best practices globally. Ultimately, the financing strategies for these targets must be set out in the planning stage to ensure that social, economic, and environmental challenges are accounted for.

As such, communication and stewardship across governments, as well as national departments and agencies, must be improved to create an integrated ocean management plan. A collaborative effort is essential for the proper planning and management of Red Sea resources (see "Actors" in Table 1). This will, among other things, require the active involvement 
of third parties and organizations, such as conservation NGOs and The Regional Organization for the Conservation of the Environment in the Red Sea and the Gulf of Aden, to help mediate (Fine et al., 2019). However, such regulatory bodies must be sufficiently empowered to enforce regulations and provide accountability to non-compliance. Inevitably, the effective delivery and rapid implementation of blue natural capitalrelated policies will depend on communication, transparency, accountability, and inclusivity (Hejnowicz et al., 2015).

Ultimately, all the above outlined action steps that are required to ensure the future of blue natural capital build on the core principle of collaboration, integration of regional scale planning and organized actions across multiple stakeholders and nations. Whether it is the implementation of the MPAs or baseline assessments of ecosystems, countries bordering the Red Sea will have to strategically decide how best to overcome geopolitical barriers and prevent competitive exploitation (as seen in Table 1). Several countries have already signed bilateral agreements, such as Egypt-Jordan ("Cooperation Agreement between Egypt and Jordan in fisheries resources," 1,999) or Jordan-Saudi Arabia ("Bilateral Economic Agreement between Jordan and Saudi Arabia," $1,962)$, but these likely require re-addressing. The challenge here will be to find a way to balance economic, political and environmental resources available to the different nations. This will be particularly important when considering factors such as; financial support, access to technology, knowledge development and sharing, socio-economic benefits and their, distribution, and international contributions. Due to the collaborative nature and strong political will required of the action steps, their implementation will take a more nuanced understanding of collaborative governance and how they may be most effectively implemented to solve environment problems (Bodin, 2017). As such, it is imperative that in the interim a precautionary approach is applied, for example in the form of stronger national commitments and enforcements of policies, as well as voluntary actions by industry and private sectors.

As concepts of blue economy are growing in momentum in the global political landscape and associated policies are being implemented, there is a need to critically analyze their impacts on the people that currently rely on blue resources (Barbesgaard, 2018). Collaborative approaches play a key role in addressing environmental problems, but multi-actor collaboration needs to consider social and ecological structures (Bodin, 2017). Providing livelihood and income resources (and potential alternatives), increased awareness and education and consultation of local communities will be essential in implementing and enacting policies. Effective policies depend on the identification and understanding of practices, expectations and interests of various different stakeholders on local and national scale (Howard et al., 2017). This includes raising awareness of how changes in marine resource use, or coastal development, will affect local stakeholders and communities, highlighting the potential financial risks and understanding the different timeframes required in order to generate social and economic benefits (Howard et al., 2017). If communities and stakeholders are not aware of the finer details of new policy and are not integrated into the decision of new conservation and policy options, the risk of failure for long term implementation and expansion of these efforts increases. Furthermore, financialization of blue projects needs to overcome challenges of equity and ensure that the redistribution of social power includes regions' communities (Sullivan, 2013; Knott and Neis, 2017). The challenges, and absolute necessity, of developing an equitable and inclusive governance of the blue economy have become an increasingly central theme as awareness regarding the risks of uncontrolled ocean development on marine environment and human wellbeing (Bennett et al., 2019). Thus, a sustainable blue economy needs to provide an economic environment that allows both natural and social ecosystems to flourish, ensuring an equal benefit distribution.

\section{CONCLUSION}

Here, we show why private and public sectors must invest in protecting, preserving, and enhancing blue natural capital of the Red Sea. The relatively pristine condition of many of the coral reef, seagrass, and mangrove ecosystems in the northern Red Sea and the Gulf of Aqaba, present a significant source of environmental and socio-economical investment prospects for the region. Taking advantage of these investment opportunities in natural assets could place local nations as global innovators of sustainable ocean projects and economies. However, to ensure that these environmental and financial ventures are enacted sustainably (without the loss of local biodiversity) and return a profit in the long term, significant proactive policies to protect and restore the wealth of blue natural capital in the Red Sea are required. Sustainable ocean management is, in its essence, a political process that requires coordination across governments as well as relevant stakeholders, including scientists, local communities, and industries. This model of inclusive governance will be central to ensuring an equitable and just development of the blue economy. Hence, communication, participation, and transparency of all involved parties are required to successfully build a blue economy that thrives with its natural resources. Considering the opportunities at stake, failure to invest in the Red Sea's blue natural capital would represent a substantial loss - economically and, most importantly, environmentally and socially.

\section{AUTHOR CONTRIBUTIONS}

$\mathrm{MC}, \mathrm{CD}$, and MA conceived the idea. MC wrote the manuscript. $\mathrm{MC}$ and MA worked on revisions. All authors contributed critical feedback. 


\section{REFERENCES}

Ahmed, N., and Glaser, M. (2016). Coastal aquaculture, mangrove deforestation and blue carbon emissions: is REDD+ a solution? Mar. Policy 66, 58-66. doi: 10.1016/j.marpol.2016.01.011

Ahmed, N., and Thompson, S. (2019). The blue dimensions of aquaculture: a global synthesis. Sci. Tot. Environ. 652, 851-861. doi:.1016/j.scitotenv.2018.10.163 doi: 10.1016/j.scitotenv.2018.10.163

Almahasheer, H., Aljowair, A., Duarte, C. M., and Irigoien, X. (2016). Decadal stability of Red Sea mangroves. Estuar. Coast. Shelf Sci. 169, 164-172. doi: 10.1016/J.ECSS.2015.11.027

Anton, A., Baldry, K., Coker, D. J., and Duarte, C. M. (2020a). Drivers of the low metabolic rates of seagrass meadows in the Red Sea. Front. Mar. Sci. 7:69. doi: 10.3389/fmars.2020.00069

Anton, A., Randle, J. L., Garcia, F. C., Rossbach, S., Ellis, J. I., Weinzierl, M., et al. (2020b). Differential thermal tolerance between algae and corals may trigger the proliferation of algae in coral reefs. Glob. Change Biol. 26, 4316-4327. doi: $10.1111 /$ gcb.15141

Ashok, A., Cusack, M., Saderne, V., Krishnakumar, P. K., Rabaoui, L., Qurban, M. A., et al. (2019). Accelerated burial of petroleum hydrocarbons in Arabian Gulf blue carbon repositories. Sci. Tot. Environ. 669, 205-212. doi: 10.1016/j. scitotenv.2019.01.437

Bailey, G. (2010). The Red Sea, Coastal Landscapes, and Hominin Dispersals. Dordrecht: Springer, 15-37.

Bailey, I. (2002). European environmental taxes and charges: economic theory and policy practice. Appl. Geogr. 22, 235-251. doi: 10.1016/S0143-6228(02)00011-5

Barbesgaard, M. (2018). Blue growth: savior or ocean grabbing? J. Peasant Stud. 45, 130-149. doi: 10.1080/03066150.2017.1377186

Baums, I. B., Baker, A. C., Davies, S. W., Grottoli, A. G., Kenkel, C. D., Kitchen, S. A., et al. (2019). Considerations for maximizing the adaptive potential of restored coral populations in the western Atlantic. Ecol. Applic. 29:e01978. doi: 10.1002/eap.1978

Bayraktarov, E., Saunders, M. I., Abdullah, S., Mills, M., Beher, J., Possingham, H. P., et al. (2016). The cost and feasibility of marine coastal restoration. Ecol. Applic. 26, 1055-1074. doi: 10.1890/15-1077

Bennett, N. J., Cisneros-Montemayor, A. M., Blythe, J., Silver, J. J., Singh, G., Andrews, N., et al. (2019). Towards a sustainable and equitable blue economy. Nat. Sustainab. 2, 991-993. doi: 10.1038/s41893-019-0404-1

Bennett, N. J., Govan, H., and Satterfield, T. (2015). Ocean grabbing. Mar. Policy 57, 61-68. doi: 10.1016/j.marpol.2015.03.026

Berumen, M. L., Hoey, A. S., Bass, W. H., Bouwmeester, J., Catania, D., Cochran, J. E. M., et al. (2013). The status of coral reef ecology research in the Red Sea. Coral Reefs 32, 737-748. doi: 10.1007/s00338-013-1055-8

Blignaut, J., Aronson, J., and de Groot, R. (2014). Restoration of natural capital: a key strategy on the path to sustainability. Ecol. Eng. 65, 54-61. doi: 10.1016/J. ECOLENG.2013.09.003

Blockley, A., Elliott, D., Roberts, A., and Sweet, M. (2017). Symbiotic microbes from marine invertebrates: driving a new era of natural product drug discovery. Diversity 9:49. doi: 10.3390/d9040049

Bodin, Ö (2017). Collaborative environmental governance: achieving collective action in social-ecological systems. Science 357:eaan1114. doi: 10.1126/science. aan1114

Branchini, S., Pensa, F., Neri, P., Tonucci, B. M., Mattielli, L., Collavo, A., et al. (2015). Using a citizen science program to monitor coral reef biodiversity through space and time. Biodivers. Conserv. 24, 319-336. doi: 10.1007/s10531014-0810-7

Burt, J. A., and Bartholomew, A. (2019). Towards more sustainable coastal development in the Arabian Gulf: opportunities for ecological engineering in an urbanized seascape. Mar. Pollut. Bull. 142, 93-102. doi: 10.1016/j.marpolbul. 2019.03.024

Caro, T., Darwin, J., Forrester, T., Ledoux-Bloom, C., and Wells, C. (2012). Conservation in the anthropocene. Conserv. Biol. 26, 185-188. doi: 10.1111/j. 1523-1739.2011.01752.x

Chaidez, V., Dreano, D., Agusti, S., Duarte, C. M., and Hoteit, I. (2017). Decadal trends in Red Sea maximum surface temperature. Sci. Rep. 7:8144. doi: 10.1038/ s41598-017-08146-z

Chamberland, V. F., Petersen, D., Guest, J. R., Petersen, U., Brittsan, M., and Vermeij, M. J. A. (2017). New seeding approach reduces costs and time to outplant sexually propagated corals for reef restoration. Sci. Rep. 7:18076. doi: 10.1038/s41598-017-17555-z

Craggs, J., Guest, J. R., Davis, M., Simmons, J., Dashti, E., and Sweet, M. (2017). Inducing broadcast coral spawning ex situ: closed system mesocosm design and husbandry protocol. Ecol. Evol. 7, 11066-11078. doi: 10.1002/ece3.3538

Cuellar-Gempeler, C., and Leibold, M. A. (2018). Multiple colonist pools shape fiddler crab-associated bacterial communities. ISME J. 12, 825-837. doi: 10 . 1038/s41396-017-0014-8

Curran, M., Hellweg, S., and Beck, J. (2014). Is there any empirical support for biodiversity offset policy? Ecol. Applic. 24, 617-632. doi: 10.1890/13-0243.1

Cziesielski, M. J., Schmidt-Roach, S., and Aranda, M. (2019). The past, present, and future of coral heat stress studies. Ecol. Evol. 9, 10055-10066. doi: 10.1002/ece3. 5576

Dafforn, K. A., Glasby, T. M., Airoldi, L., Rivero, N. K., Mayer-Pinto, M., and Johnston, E. L. (2015). Marine urbanization: an ecological framework for designing multifunctional artificial structures. Front. Ecol. Environ. 13, 82-90. doi: 10.1890/140050

Davy, S. K., Allemand, D., and Weis, V. M. (2012). Cell biology of cnidariandinoflagellate symbiosis. Microbiol. Mol. Biol. Rev. MMBR 76, 229-261. doi: 10.1128/MMBR.05014-11

Day, J. (2008). The need and practice of monitoring, evaluating and adapting marine planning and management-lessons from the Great Barrier Reef. Mar. Policy 32, 823-831. doi: 10.1016/J.MARPOL.2008.03.023

de Groot, R., Brander, L., van der Ploeg, S., Costanza, R., Bernard, F., Braat, L., et al. (2012). Global estimates of the value of ecosystems and their services in monetary units. Ecosyst. Serv. 1, 50-61. doi: 10.1016/J.ECOSER.2012. 07.005

Destoumieux-Garzón, D., Mavingui, P., Boetsch, G., Boissier, J., Darriet, F., Duboz, P., et al. (2018). The one health concept: 10 years old and a long road ahead. Front. Vet. Sci. 5:14. doi: 10.3389/fvets.2018.00014

DiBattista, J. D., Howard Choat, J., Gaither, M. R., Hobbs, J.-P. A., Lozano-Cortés, D. F., Myers, R. F., et al. (2016). On the origin of endemic species in the Red Sea. J. Biogeogr. 43, 13-30. doi: 10.1111/jbi.12631

Dixon, G. B., Davies, S. W., Aglyamova, G. A. V., Meyer, E., Bay, L. K., and Matz, M. V. (2015). Genomic determinants of coral heat tolerance across latitudes. Science 348, 1460-1462. doi: 10.1126/science.1261224

Donato, D. C., Kauffman, J. B., Murdiyarso, D., Kurnianto, S., Stidham, M., and Kanninen, M. (2011). Mangroves among the most carbon-rich forests in the tropics. Nat. Geosci. 4, 293-297. doi: 10.1038/ngeo1123

Dorenbosch, M., Grol, M. G. G., Nagelkerken, I., and van der Velde, G. (2006). Seagrass beds and mangroves as potential nurseries for the threatened Indo-Pacific humphead wrasse, Cheilinus undulatus and Caribbean rainbow parrotfish, Scarus guacamaia. Biol. Conserv. 129, 277-282. doi: 10.1016/J. BIOCON.2005.10.032

Duarte, C. M. (2014). Red ochre and shells: clues to human evolution. Trends Ecol. Evol. 29, 560-565. doi: 10.1016/j.tree.2014.08.002

Duarte, C. M., Delgado-Huertas, A., Anton, A., Carrillo-de-Albornoz, P., LópezSandoval, D. C., Agustí, S., et al. (2018). Stable isotope ( $\delta 13 \mathrm{C}, \delta 15 \mathrm{~N}, \delta 18 \mathrm{O}, \delta \mathrm{D})$ composition and nutrient concentration of red sea primary producers. Front. Mar. Sci. 5:298. doi: 10.3389/fmars.2018.00298

Duarte, C. M., Losada, I. J., Hendriks, I. E., Mazarrasa, I., and Marbà, N. (2013). The role of coastal plant communities for climate change mitigation and adaptation. Nat. Clim. Change 3, 961-968. doi: 10.1038/nclimate1970

Duarte, C. M., Marbà, N., Gacia, E., Fourqurean, J. W., Beggins, J., Barrón, C., et al. (2010). Seagrass community metabolism: assessing the carbon sink capacity of seagrass meadows. Glob. Biogeochem. Cycles 24:GB003793. doi: 10.1029/ 2010GB003793

Duarte, C. M., Middelburg, J. J., and Caraco, N. (2004). Major role of marine vegetation on the oceanic carbon cycle. Biogeosciences Discussions, European Geosciences Union 1, 659-679.

Earp, H. S., Prinz, N., Cziesielski, M. J., and Andskog, M. (2018). "For a world without boundaries: connectivity between marine tropical ecosystems in times of change," in YOUMARES 8 - Oceans Across Boundaries: Learning from Each Other, eds S. Jungblut, M. Bode, and V. Liebich (Cham: Speinger).

Ehler, C., and Douvere, F. (2009). Marine Spatial Planning: a Step-By-Step Approach Toward Ecosystem-Based Management. Intergovernmental Oceanographic Commission and Man and the Biosphere Programme. Available online at: https: //repository.oceanbestpractices.org/handle/11329/459 (accessed May 15, 2020). 
Ellison, J. C. (2015). Vulnerability assessment of mangroves to climate change and sea-level rise impacts. Wetlands Ecol. Manag. 23, 115-137. doi: 10.1007/s11273014-9397-8

European Comission (2018). The 2018 Annual Economic Report on EU Blue Economy. Available online at: https://ec.europa.eu/maritimeaffairs/sites/ maritimeaffairs/files/2018-annual-economic-report-on-blue-economy_en.pdf (accessed November 26, 2020).

Feary, D. A., Burt, J. A., and Bartholomew, A. (2011). Artificial marine habitats in the Arabian Gulf: review of current use, benefits and management implications. Ocean Coast. Manag. 54, 742-749. doi: 10.1016/j.ocecoaman.2011.07.008

Feidi, I. H. (2009). Red Sea and Gulf of Aden Fisheries. Available online at: https://www.researchgate.net/publication/334598667_RED_SEA_AND_ GULF_OF_ADEN_FISHERIES_5 (accessed November 29, 2020).

Fine, M., Cinar, M., Voolstra, C. R., Safa, A., Rinkevich, B., Laffoley, D., et al. (2019). Coral reefs of the Red Sea - Challenges and potential solutions. Region. Stud. Mar. Sci. 25:100498. doi: 10.1016/J.RSMA.2018.100498

Fine, M., Gildor, H., and Genin, A. (2013). A coral reef refuge in the Red Sea. Glob. Change Biol. 19, 3640-3647. doi: 10.1111/gcb.12356

Forsskål, P., Forsskål, P., and Niebuhr, C. (1775). Descriptiones Animalium, Avium, Amphibiorum, Piscium, Insectorum, Vermium. Hauniæ: ex officina Mölleri.

Fujita, R., Lynham, J., Micheli, F., Feinberg, P. G., Bourillón, L., Sáenz-Arroyo, A., et al. (2013). Ecomarkets for conservation and sustainable development in the coastal zone. Biol. Rev. 88, 273-286. doi: 10.1111/j.1469-185X.2012.00251.x

Garcias-Bonet, N., Delgado-Huertas, A., Carrillo-de-Albornoz, P., Anton, A., Almahasheer, H., Marbà, N., et al. (2019). Carbon and nitrogen concentrations, stocks, and isotopic compositions in red sea seagrass and mangrove sediments. Front. Mar. Sci. 6:267. doi: 10.3389/fmars.2019.00267

Genevier, L. G. C., Jamil, T., Raitsos, D. E., Krokos, G., and Hoteit, I. (2019). Marine heatwaves reveal coral reef zones susceptible to bleaching in the Red Sea. Glob. Change Biol. 25, 2338-2351. doi: 10.1111/gcb.14652

Giomi, F., Barausse, A., Duarte, C. M., Booth, J., Agusti, S., Saderne, V., et al. (2019). Oxygen supersaturation protects coastal marine fauna from ocean warming. Sci. Adv. 5:eaax1814. doi: 10.1126/sciadv.aax1814

Hagedorn, M., Spindler, R., and Daly, J. (2019). Cryopreservation as a Tool for Reef Restoration: 2019. Cham: Springer, 489-505.

Halfar, J., and Fujita, R. M. (2002). Precautionary management of deep-sea mining. Mar. Policy 26, 103-106. doi: 10.1016/S0308-597X(01)00041-0

Hall, A. E., Herbert, R. J. H., Britton, J. R., and Hull, S. L. (2018). Ecological enhancement techniques to improve habitat heterogeneity on coastal defence structures. Estuar.Coast. Shelf Sci. 210, 68-78. doi: 10.1016/J.ECSS.2018.05.025

Hamza, M., Alhasseen, I., and Mohamed, S. (2017). Contribution of fishery production and marketing sector in the household food security in the Red Sea State, Sudan. Am. Sci. Res. J. Eng. Technol. Sci. 31, 176-182.

Hansen, T. (1962). Arabia Felix: The Danish Expedition of 1761-1767 - Thorkild Hansen - Google Books. New York, NY: New York Review Books.

Hariri, K. I., Nichols, P., Krupp, F., Mishrigi, S., Barrania, A., Ali, A. F., et al. (2002). Strategic Action Programme for the Red Sea and Gulf of Aden Status of the Living Marine Resources in the Red Sea and Gulf of Aden and Their Management Regional Organization for the Conservation of the Environment of the Red Sea and Gulf of Aden PERSGA 2002 The International Bank for Reconstruction and Development/ THE WORLD BANK. Available online at: http://www.persga.org/ Documents/Vol3bStatusofLMRinRSGA.pdf (accessed June 20, 2020).

He, E. X. (2016). How Carbon Trading Can Help Preserve Coastal Ecosystems. Available online at: http://climate.org/wp-content/uploads/2016/12/CarbonTrading-Coastal-Ecosystems.pdf (accessed June 7, 2020).

Hejnowicz, A. P., Kennedy, H., Rudd, M. A., and Huxham, M. R. (2015). Harnessing the climate mitigation, conservation and poverty alleviation potential of seagrasses: prospects for developing blue carbon initiatives and payment for ecosystem service programmes. Front. Mar. Sci. 2:32. doi: 10.3389/ fmars.2015.00032

Himes-Cornell, A., Pendleton, L., and Atiyah, P. (2018). Valuing ecosystem services from blue forests: a systematic review of the valuation of salt marshes, sea grass beds and mangrove forests. Ecosyst. Serv. 30, 36-48. doi: 10.1016/j.ecoser.2018. 01.006

Hoegh-Guldberg, O., Kennedy, E. V., Beyer, H. L., McClennen, C., and Possingham, H. P. (2018). Securing a long-term future for coral reefs. Trends Ecol. Evol. 33, 936-944. doi: 10.1016/J.TREE.2018.09.006
Horoszowski-Fridman, Y. B., and Rinkevich, B. (2016). "Restoration of the animal forests: harnessing silviculture biodiversity concepts for coral transplantation," in Marine Animal Forests, eds L. Bramanti, A. Gori, C. Orejas, and S. Rossi (Cham: Springer International Publishing), 1-23. doi: 10.1007/978-3-31917001-5_36-1

Howard, J., Sutton-Grier, A., Herr, D., Kleypas, J., Landis, E., Mcleod, E., et al. (2017). Clarifying the role of coastal and marine systems in climate mitigation. Front. Ecol. Environ. 15, 42-50. doi: 10.1002/fee.1451

Howells, E. J., Abrego, D., Meyer, E., Kirk, N. L., and Burt, J. A. (2016). Host adaptation and unexpected symbiont partners enable reef-building corals to tolerate extreme temperatures. Glob. Change Biol. 22, 2702-2714. doi: 10.1111/ gcb. 13250

Hughes, T. P., Kerry, J. T., Baird, A. H., Connolly, S. R., Dietzel, A., Eakin, C. M., et al. (2018). Global warming transforms coral reef assemblages. Nature 556, 492-496. doi: 10.1038/s41586-018-0041-2

Ido, S., and Shimrit, P.-F. (2015). Blue is the new green - Ecological enhancement of concrete based coastal and marine infrastructure. Ecol. Eng. 84, 260-272. doi: 10.1016/J.ECOLENG.2015.09.016

Jackson, E. L., Rees, S., Siân, E., Wilding, C., and Attrill, M. J. (2015). Use of a seagrass residency index to apportion commercial fishery landing values and recreation fisheries expenditure to seagrass habitat service. Conserv. Biol. 29, 899-909. doi: 10.1111/cobi.12436

Janson, S., Siddiqui, P. J. A., Walsby, A. E., Romans, K. M., Carpenter, E. J., and Bergman, B. (1995). Cytomorphological characterization of the planktonic diazotrophic cyanobacteria Trichodesmium spp. from the Indian Ocean and Caribbean and Sargasso Seas1. J. Phycol. 31, 463-477. doi: 10.1111/j.0022-3646. 1995.00463.x

Jouffray, J.-B., Blasiak, R., Norström, A. V., Österblom, H., and Nyström, M. (2020). The blue acceleration: the trajectory of human expansion into the Ocean. One Earth 2, 43-54. doi: 10.1016/j.oneear.2019.12.016

Kareiva, P., and Marvier, M. (2012). What is conservation science? BioScience 62, 962-969. doi: 10.1525/bio.2012.62.11.5

Kelly, C., Gray, L., Shucksmith, R., and Tweddle, J. F. (2014). Review and evaluation of marine spatial planning in the Shetland Islands. Mar. Policy 46, 152-160. doi: 10.1016/J.MARPOL.2014.01.017

Kirk, N. L., Howells, E. J., Abrego, D., Burt, J. A., and Meyer, E. (2018). Genomic and transcriptomic signals of thermal tolerance in heat-tolerant corals (Platygyra daedalea) of the Arabian/Persian Gulf. Mol. Ecol. 27, 5180-5194. doi: 10.1111/mec.14934

Kleinhaus, K., Al-Sawalmih, A., Barshis, D. J., Genin, A., Grace, L. N., HoeghGuldberg, O., et al. (2020). Science, diplomacy, and the Red Sea's unique coral reef: it's time for action. Front. Mar. Sci. 7:90. doi: 10.3389/fmars.2020. 00090

Knott, C., and Neis, B. (2017). Privatization, financialization and ocean grabbing in New Brunswick herring fisheries and salmon aquaculture. Mar. Policy 80, 10-18. doi: 10.1016/j.marpol.2016.10.022

Knowlton, N., Lang, J. C., and Keller, B. D. (1990). Case study of natural population collapse: post-hurricane predation on Jamaican staghorn corals. Smithsonian Contrib. Mar. Sci. 31, 1-25. doi: 10.5479/si.01960768.31.1

Krueger, T., Horwitz, N., Bodin, J., Giovani, M. E., Escrig, S., Meibom, A., et al. (2017). Common reef-building coral in the northern red sea resistant to elevated temperature and acidification. R. Soc. Open Sci. 4:170038. doi: 10.1098/rsos. 170038

LaJeunesse, T. C., Parkinson, J. E., Gabrielson, P. W., Jeong, H. J., Reimer, J. D., Voolstra, C. R., et al. (2018). Systematic revision of symbiodiniaceae highlights the antiquity and diversity of coral endosymbionts. Curr. Biol. 28, 2570.e62580.e6. doi: 10.1016/J.CUB.2018.07.008

Langergraber, G., Pucher, B., Simperler, L., Kisser, J., Katsou, E., Buehler, D., et al. (2020). Implementing nature-based solutions for creating a resourceful circular city. Blue Green Syst. 2, 173-185. doi: 10.2166/bgs.20 20.933

Lin, H., and Nakamura, M. (2012). Payments for watershed services: directing incentives for improving lake basin governance. Lakes Reservoirs Res. Manag. 17, 191-206. doi: 10.1111/lre.12004

Liversage, K., and Chapman, M. (2018). Coastal ecological engineering and habitat restoration: incorporating biologically diverse boulder habitat. Mar. Ecol. Prog. Ser. 593, 173-185. doi: 10.3354/meps12541 
Lovelock, C. E., Atwood, T., Baldock, J., Duarte, C. M., Hickey, S., Lavery, P. S., et al. (2017). Assessing the risk of carbon dioxide emissions from blue carbon ecosystems. Front. Ecol. Environ. 15, 257-265. doi: 10.1002/fee.1491

Mabrouk, A. (2015). The Role of Marine Protected Areas in Maintaining Sustainable Fisheries in the Egyptian Gulf of Aqaba, Red Sea | MSU Libraries. Michigan: Michigan State University.

Macreadie, P. I., Anton, A., Raven, J. A., Beaumont, N., Connolly, R. M., Friess, D. A., et al. (2019). The future of Blue Carbon science. Nat. Commun. 10:3998. doi: 10.1038/s41467-019-11693-w

Manzello, D. P., Matz, M. V., Enochs, I. C., Valentino, L., Carlton, R. D., Kolodziej, G., et al. (2018). Role of host genetics and heat tolerant algal symbionts in sustaining populations of the endangered coral Orbicella faveolata in the Florida Keys with ocean warming. Glob. Change Biol. 25, 1016-1031. doi: 10.1111/gcb. 14545

Marine Conservation Institute (2019). MPAtlas [Online]. Seattle, WA: Marine Conservation Institute.

Marshall, N. A., Marshall, P. A., Abdulla, A., and Rouphael, T. (2010). The links between resource dependency and attitude of commercial fishers to coral reef conservation in the red sea. Ambio 39, 305-313. doi: 10.1007/s13280-010-00659

Marshall, N. J., Kleine, D. A., and Dean, A. J. (2012). CoralWatch: education, monitoring, and sustainability through citizen science. Front. Ecol. Environ. 10, 332-334. doi: 10.1890/110266

Martin, C., Almahasheer, H., and Duarte, C. M. (2019). Mangrove forests as traps for marine litter. Environ. Pollut. 247, 499-508. doi: 10.1016/j.envpol.2019.01. 067

Martin, C., Baalkhuyur, F., Valluzzi, L., Saderne, V., Cusack, M., Almahasheer, H., et al. (2020). Exponential increase of plastic burial in mangrove sediments as a major plastic sink. Sci. Adv. 6:eaaz5593. doi: 10.1126/sciadv.aaz5593

Mayer-Pinto, M., Dafforn, K. A., and Johnston, E. L. (2019). A decision framework for coastal infrastructure to optimize biotic resistance and resilience in a changing climate. BioScience 69, 833-843. doi: 10.1093/biosci/ biz092

McCook, L. J., Jompa, J., and Diaz-Pulido, G. (2001). Competition between corals and algae on coral reefs: a review of evidence and mechanisms. Coral Reefs 19, 400-417. doi: 10.1007/s003380000129

Mcleod, E., Chmura, G. L., Bouillon, S., Salm, R., Björk, M., Duarte, C. M., et al. (2011). A blueprint for blue carbon: toward an improved understanding of the role of vegetated coastal habitats in sequestering CO 2. Front. Ecol. Environ. 9, 552-560. doi: 10.1890/110004

Miller, T. R., Minteer, B. A., and Malan, L. C. (2011). The new conservation debate: the view from practical ethics. Biol. Conserv. 144, 948-957. doi: 10.1016/ j.biocon.2010.04.001

Moberg, F., and Folke, C. (1999). Ecological goods and services of coral reef ecosystems. Ecol. Econ. 29, 215-233. doi: 10.1016/S0921-8009(99)00009-9

Mohamed, A. R., and Sweet, M. (2019). Current Knowledge of Coral Diseases Present Within the Red Sea. Cham: Springer, 387-400.

Monroe, A. A., Ziegler, M., Roik, A., Röthig, T., Hardenstine, R. S., Emms, M. A., et al. (2018). In situ observations of coral bleaching in the central Saudi Arabian Red Sea during the 2015/2016 global coral bleaching event. PLoS One 13:e0195814. doi: 10.1371/journal.pone.0195814

Mumby, P. J., Hastings, A., and Edwards, H. J. (2007). Thresholds and the resilience of Caribbean coral reefs. Nature 450, 98-101. doi: 10.1038/nature06252

Nellemann, C., Corcoran, E., Duarte, C. M., Valdeìs, L., De Young, C., Fonseca, L., et al. (2009). Blue carbon: a rapid response assessment. Environment Available at: https://portals.iucn.org/library/node/9442 (accessed July 13, 2020).

Nordlund, L. M., Unsworth, R. K. F., Gullström, M., and Cullen-Unsworth, L. C. (2018). Global significance of seagrass fishery activity. Fish Fish. 19, 399-412. doi: $10.1111 /$ faf.12259

OECD (2016). The Ocean Economy in 2030. Paris: OECD.

OECD (2019). Rethinking Innovation for a Sustainable Ocean Economy. Paris: OECD.

Osman, E. O., Smith, D. J., Ziegler, M., Kürten, B., Conrad, C., El-Haddad, K. M., et al. (2018). Thermal refugia against coral bleaching throughout the northern Red Sea. Glob. Change Biol. 24, e474-e484. doi: 10.1111/gcb.13895

Peng, Y., Li, X., Wu, K., Peng, Y., and Chen, G. (2009). Effect of an integrated mangrove-aquaculture system on aquacultural health. Front. Biol. China 4, 579-584. doi: 10.1007/s11515-009-0056-z
PERSGA (2004). The Regional Organization for the Conservation of the Environment of the Red Sea and Gulf of Aden Status of Mangroves in the Red Sea and Gulf of Aden. Available online at: http://www.persga.org

Potouroglou, M., Bull, J. C., Krauss, K. W., Kennedy, H. A., Fusi, M., Daffonchio, D., et al. (2017). Measuring the role of seagrasses in regulating sediment surface elevation. Sci. Rep. 7, 1-11. doi: 10.1038/s41598-017-12354-y

Qurban, M. A. B., Karuppasamy, M., Krishnakumar, P. K., Garcias-Bonet, N., and Duarte, C. M. (2019). "Seagrass distribution, composition and abundance along the saudi arabian coast of Red Sea," in Oceanographic and Biological Aspects of the Red Sea, eds N. Rasul and I. Stewart (Cham: Springer), 367-385. doi: 10.1007/978-3-319-99417-8_20

Rabaoui, L., Cusack, M., Saderne, V., Krishnakumar, P. K., Lin, Y.-J., Shemsi, A. M., et al. (2020). Anthropogenic-induced acceleration of elemental burial rates in blue carbon repositories of the Arabian Gulf. Sci. Tot. Environ. 719:135177. doi: 10.1016/j.scitotenv.2019.135177

Raitsos, D. E., Pradhan, Y., Brewin, R. J. W., Stenchikov, G., and Hoteit, I. (2013). Remote sensing the phytoplankton seasonal succession of the Red Sea. PLoS One 8:e64909. doi: 10.1371/journal.pone.0064909

Rinkevich, B. (2015). Novel tradable instruments in the conservation of coral reefs, based on the coral gardening concept for reef restoration. J. Environ. Manage. 162, 199-205. doi: 10.1016/J.JENVMAN.2015.07.028

Roberts, C. M. (1997). Connectivity and management of caribbean coral reefs. Science 278, 1454-1457. doi: 10.1126/science.278.5342.1454

Rosado, P. M., Leite, D. C. A., Duarte, G. A. S., Chaloub, R. M., Jospin, G., Nunes da Rocha, U., et al. (2019). Marine probiotics: increasing coral resistance to bleaching through microbiome manipulation. ISME J. 13, 921-936. doi: 10. 1038/s41396-018-0323-6

Roy, J., Tscharket, P., Waisman, H., Abdul Halim, S., Antwi-Agyei, P., Dasgupta, P., et al. (2018). Sustainable Development, Poverty Eradication and Reducing Inequalities. Available online at: https://www.ipcc.ch/sr15/ (accessed November 14, 2020).

Samy, M., Sánchez Lizaso, J. L., and Forcada, A. (2011). Status of marine protected areas in Egypt. Anim. Biodivers. Conserv. 34, 165-177.

Saderne, V., Cusack, M., Almahasheer, H., Serrano, O., Masqué, P., AriasOrtiz, A., et al. (2018). Accumulation of carbonates contributes to coastal vegetated ecosystems keeping pace with sea level rise in an Arid Region (Arabian Peninsula). J. Geophys. Res. Biogeosci. 123, 1498-1510. doi: 10.1029/ 2017JG004288

Sanderman, J., Hengl, T., Fiske, G., Solvik, K., Adame, M. F., Benson, L., et al. (2018). A global map of mangrove forest soil carbon at 30 ? $\mathrm{m}$ spatial resolution. Environ. Res. Lett. 13:055002. doi: 10.1088/1748-9326/aabe1c

Satyanarayana, B., Bhanderi, P., Debry, M., Maniatis, D., Foré, F., Badgie, D., et al. (2012). A socio-ecological assessment aiming at improved forest resource management and sustainable ecotourism development in the mangroves of tanbi Wetland National Park, The Gambia, West Africa. AMBIO 41, 513-526. doi: $10.1007 /$ s13280-012-0248-7

Schachtner, E. (2017). "Marine protected areas and marine spatial planning, with special reference to the Black Sea," in Management of Marine Protected Areas, ed. P. D. Goriup (Chichester: John Wiley \& Sons, Ltd), 207-226. doi: 10.1002/ 9781119075806.ch11

Schmidt-Roach, S., Duarte, C. M., Hauser, C. A. E., and Aranda, M. (2020). Beyond reef restoration: next-generation techniques for coral gardening, landscaping, and outreach. Front. Mar. Sci. 7:672. doi: 10.3389/fmars.2020.00672

Schneider, P. (2011). The discovery of tropical mangroves in graecoroman antiquity: science and wonder. J. Hakluyt Soc. Available at: https://www.academia.edu/7635491/The_Discovery_of_Tropical_Mangroves_ in_Graeco_Roman_Antiquity_Science_and_Wonder (accessed July 12, 2020).

Schopmeyer, S. A., Lirman, D., Bartels, E., Gilliam, D. S., Goergen, E. A., Griffin, S. P., et al. (2017). Regional restoration benchmarks for Acropora cervicornis. Coral Reefs 36, 1047-1057. doi: 10.1007/s00338-017-1596-3

Shaltout, K. H., Ahmed, M. T., Alrumman, S. A., Ahmed, D. A., and Eid, E. M. (2020). Evaluation of the carbon sequestration capacity of arid mangroves along nutrient availability and salinity gradients along the Red Sea coastline of Saudi Arabia. Oceanologia 62, 56-69. doi: 10.1016/j.oceano.2019.08.002

Shishlov, I., and Morel, R. (2016). Beyond Transparency: Unlocking the Full Potential of Green Bonds EXECUTIVE SUMMARY 4. Available online at: https://www.i4ce.org/wp-core/wp-content/uploads/2016/06/I4CE_Green_ Bonds-1.pdf (accessed August 19, 2020). 
Short, F., Carruthers, T., Dennison, W., and Waycott, M. (2007). Global seagrass distribution and diversity: a bioregional model. J. Exp. Mar. Biol. Ecol. 350, 3-20. doi: 10.1016/J.JEMBE.2007.06.012

Soldan, R., Mapelli, F., Crotti, E., Schnell, S., Daffonchio, D., Marasco, R., et al. (2019). Bacterial endophytes of mangrove propagules elicit early establishment of the natural host and promote growth of cereal crops under salt stress. Microbiol. Res. 223, 33-43. doi: 10.1016/j.micres.2019.03.008

Soulé, M. (2013). The “new conservation". Conserv. Biol. 27, 895-897. doi: 10.1111/ cobi. 12147

Spalding, M., Kainuma, M., and Collins, L. (2010). World Atlas of Mangroves. London: Earthscan.

Stavins, R. N. (2001). Experience with Market-Based Environmental Policy Instruments. Available online at: https://media.rff.org/documents/RFF-DP-0158.pdf (accessed August 19, 2020).

Suggett, D. J., Camp, E. F., Edmondson, J., Boström-Einarsson, L., Ramler, V., Lohr, K., et al. (2019). Optimizing return-on-effort for coral nursery and outplanting practices to aid restoration of the Great Barrier Reef. Restoration Ecol. 27, 683-693. doi: 10.1111/rec.12916

Sullivan, S. (2013). Banking nature? The spectacular financialisation of environmental conservation. Antipode 45, 198-217. doi: 10.1111/j.1467-8330. 2012.00989.x

Sweet, M., Ramsey, A., and Bulling, M. (2017). Designer reefs and coral probiotics: great concepts but are they good practice. Biodiversity 18, 19-22. doi: 10.1080/ 14888386.2017.1307786

Tesfamichael, D. (2016). An Exploration of Ecosystem-Based Approaches for the Management of Red Sea Fisheries. Dordrecht: Springer, 111-134.

The Red Sea Development Company (2020). Marine Spatial Planning | The Red Sea Development Company. Available online at: https://www.theredsea.sa/en/ smart-sustainable/marine-spatial-planning (accessed May 15, 2020).

Trevathan-Tackett, S. M., Sherman, C. D. H., Huggett, M. J., Campbell, A. H., Laverock, B., Hurtado-McCormick, V., et al. (2019). A horizon scan of priorities for coastal marine microbiome research. Nat. Ecol. Evol. 3, 1509-1520. doi: 10.1038/s41559-019-0999-7

Unsworth, R. K. F., Nordlund, L. M., and Cullen-Unsworth, L. C. (2019). Seagrass meadows support global fisheries production. Conserv. Lett. 12:e12566. doi: 10.1111/conl.12566

van Aalst, P., Adams, M., Paterson-Jones, G., Poulsen, M., Pucher, J., Jeffrey, P., et al. (2018). Study to Support Investment for the Sustainable Development of the Blue Economy Competitive Multiple Framework Service Contracts for the Provision of Studies Related to the Future Development of Cohesion Policy and the ESI Funds (Lot 3) D13-Investment Platform Recommendation. Brussels: EU.

van Oppen, M. J. H., Gates, R. D., Blackall, L. L., Cantin, N., Chakravarti, L. J., Chan, W. Y., et al. (2017). Shifting paradigms in restoration of the world's coral reefs. Glob. Change Biol. 23, 3437-3448. doi: 10.1111/gcb.13647

van Oppen, M. J. H., Oliver, J. K., Putnam, H. M., and Gates, R. D. (2015). Building coral reef resilience through assisted evolution. Proc. Natl. Acad. Sci. U.S.A. 112, 2307-2313. doi: 10.1073/pnas. 1422301112
Vierros, M. (2013). Communities and blue carbon: the role of traditional management systems in providing benefits for carbon storage, biodiversity conservation and livelihoods. Clim. Change 140, 89-100. doi: 10.1007/s10584013-0920-3

Visbeck, M., Kronfeld-Goharani, U., Neumann, B., Rickels, W., Schmidt, J., van Doorn, E., et al. (2014). Securing blue wealth: the need for a special sustainable development goal for the ocean and coasts. Mar. Policy 48, 184-191. doi: 10. 1016/J.MARPOL.2014.03.005

Voolstra, C. R., and Berumen, M. L. (2019). Coral Reefs of the Red Sea. Berlin: Springer.

Walter, R. C., Buffler, R. T., Bruggemann, J. H., Guillaume, M. M. M., Berhe, S. M., Negassi, B., et al. (2000). Early human occupation of the Red Sea coast of Eritrea during the last interglacial. Nature 405, 65-69. doi: 10.1038/3501 1048

Ward, R. D., Friess, D. A., Day, R. H., and Mackenzie, R. A. (2016). Impacts of climate change on mangrove ecosystems: a region by region overview. Ecosyst. Health Sustainab. 2:e01211. doi: 10.1002/ehs2. 1211

Wengrow, D. (2010). What Makes Civilization? The Ancient Near East and the Future of the West - David Wengrow - Google Books. New York: Oxford University Press.

Wenhai, L., Cusack, C., Baker, M., Tao, W., Mingbao, C., Paige, K., et al. (2019). Successful blue economy examples with an emphasis on international perspectives. Front. Mar. Sci. 6:261. doi: 10.3389/fmars.2019. 00261

Wright, J. P., Naeem, S., Hector, A., Lehman, C., Reich, P. B., Schmid, B., et al. (2006). Conventional functional classification schemes underestimate the relationship with ecosystem functioning. Ecol. Lett. 9, 111-120. doi: 10.1111/j. 1461-0248.2005.00850.x

Conflict of Interest: EF was employed by The Red Sea Development Company. PP was employed by Saudi Aramco. ST was employed by Coral Vita.

The remaining authors declare that the research was conducted in the absence of any commercial or financial relationships that could be construed as a potential conflict of interest.

Copyright (C) 2021 Cziesielski, Duarte, Aalismail, Al-Hafedh, Anton, Baalkhuyur, Baker, Balke, Baums, Berumen, Chalastani, Cornwell, Daffonchio, Diele, Farooq, Gattuso, He, Lovelock, Mcleod, Macreadie, Marba, Martin, Muniz-Barreto, Kadinijappali, Prihartato, Rabaoui, Saderne, Schmidt-Roach, Suggett, Sweet, Statton, Teicher, Trevathan-Tackett, Joydas, Yahya and Aranda. This is an openaccess article distributed under the terms of the Creative Commons Attribution License (CC BY). The use, distribution or reproduction in other forums is permitted, provided the original author(s) and the copyright owner(s) are credited and that the original publication in this journal is cited, in accordance with accepted academic practice. No use, distribution or reproduction is permitted which does not comply with these terms. 